Available online at GSC Online Press Directory

GSC Biological and Pharmaceutical Sciences

e-ISSN: 2581-3250, CODEN (USA): GBPSC2

Journal homepage: https://www.gsconlinepress.com/journals/gscbps

(RESEARCH ARTICLE)

\title{
Morpho-biometric characterization of local chicken population in Niger
}

Ousseini Moussa Hassan 1, ${ }^{*}$, Christian Keambou Tiambo ${ }^{3}$, Salissou Issa ${ }^{2}$, Karmadine Hima ${ }^{1}$, Maman Laouali Ibrahim Adamou ${ }^{1}$ and Yacoubou Bakasso ${ }^{1}$

${ }^{1}$ Abdou Moumouni University of Niamey, Faculty of Sciences and Technics BP 10662 Niamey, Niger.

${ }^{2}$ National Institute for Agronomic Research of Niger, BP 429 Niamey, Niger.

${ }_{3}^{3}$ Centre for Tropical Livestock Genetics and Health (CTGLH)-International Livestock Research Institute (ILRI), P.O. Box 30709-00100, Nairobi, Kenya.

Publication history: Received on 10 November 2020; revised on 17 November 2020; accepted on 18 November 2020

Article DOI: https://doi.org/10.30574/gscbps.2020.13.2.0369

\begin{abstract}
The present study was initiated to determine the morphobiometric characteristics of local chicken population in Niger. A total of 554 chickens (156 males and 398 females) were sampled in the four (4) agro-ecological zones of the country. A complete description by direct observation, individual weighing and body measurements were performed on the entire sample. The results of the study showed an important diversity of plumage colours in the populations studied. Out of the thirteen (13) plumages stains observed, the most common are red (13.5\%), pebbles (12.1\%), white (11.9\%), golden partridge (11.2\%) and the fawn (10.8\%). Feather distribution was normal over most of the sample (96.6\%). The main tarsal colours observed were white, grey and yellow with respectively $45.1 \%, 39.0 \%$ and $15.3 \%$. The eye colourings were mainly orange (55.1\%), yellow (31\%) and red (12.1\%). A normal ridge was observed on $99.5 \%$ of individuals while $80 \%$ had a red barbillon.
\end{abstract}

From body measurements, it appeared that only the thoracic perimeter remains decisive in the prediction of individual live weight. The average weight obtained over the whole treated sample was $1141.24 \mathrm{~g}$. An ANOVA with sex as a source of variation showed that the roosters had an average weight of $1484.24 \mathrm{~g}$ much higher than that of hens whose average was $1266.64 \mathrm{~g}$.

This study only concerned the descriptive part of the local chicken of Niger. Other aspects such as productivity remains to be elucidated to better discover the performance of the local chicken of Niger.

Keywords: characterization; Local chicken; Niger; Phenotype; Diversity

\section{Introduction}

Family poultry in sub-Saharan Africa is practiced in an extensive system in rural and peri-urban areas and responds to the culinary habits and tastes of African populations [1]. This type of farming presents savings and investment opportunities [2]. The importance of family poultry for producers is that it contributes significantly to food security, the fight against poverty and the healthy preservation of different ecotypes of local chicken. Thus, it offers employment to disadvantaged groups, especially women $[3,4]$ and requires low levels of inputs.

In Niger, the local chicken accounts for $55 \%$ of the total number of poultry species [5]. This family poultry contributes to the food security of rural Nigerian households and ensures their nutritional quality through the source of protein that

${ }^{*}$ Corresponding author: Ousseini Moussa Hassan; Email: moussah_ousseini@yahoo.fr

Abdou Moumouni University of Niamey, Faculty of Sciences and Technics BP 10662 Niamey, Niger.

Copyright (C) 2020 Author(s) retain the copyright of this article. This article is published under the terms of the Creative Commons Attribution Liscense 4.0. 
it provides to them [6]. It also contributes to poverty reduction in rural and peri-urban areas through the substantial income it generates for producers [5].

However, the characteristics of the local chicken of Niger are not well known. This lack of information could be an obstacle to a possible livestock development program for this population. Indeed, in 2012 [7], the United Nations Food and Agriculture Fund (FAO) affirmed that the phenotypic and zootechnical characterization of local chicken populations is a preliminary step in the choice of suitable genotypes and to enhance regional scale. It is within this framework that the present study was initiated to determine the morpho-biometric characteristics of local chicken populations in Nige.

\section{Material and methods}

\subsection{Samplings}

Sampling was carried out between July and August 2017 and involved 12 rural municipalities in 6 regions (Agadez, Dosso, Maradi, Tahoua, Tillabery and Zinder) representative of the four agro-ecological zones of Niger [8]. For the Sahelian and Sudanian zones, which are the main zones producing local chicken in Niger, six and three municipalities were selected respectively. In the Sahelo-Saharan zone, two municipalities were concerned against one municipality in the Saharan zone. In each of the 12 municipalities selected, two localities were targeted. A total of twenty-four (24) localities were sampled (Figure 1). The choice of localities was made in agreement with the departmental directorates of livestock of the concerned departments that are Gaya, Doutchi, Flingué, Torodi, Dakoro, Madarounfa, Ingal, Abalak, Tanout and Magaria. The choice criteria mainly concerned the seniority of the local chicken farming practice in the locality, within households, the accessibility of the locality, the availability of traditional poultry farmers. Also the distance between the selected localities within one municipality must be at least $15 \mathrm{~km}$.

On the basis of these different criteria, a total sample of 554 adult chicken was collected, including 156 males and 398 females. The sample sizes vary according to the importance of poultry farming. Thus, the ratio per village is 29 individuals in Sahelian zones, 25 in the Sahelo-Sudanese zone, 19 individuals in the Sahelo-Saharan zone and 10 in the Saharan zone.

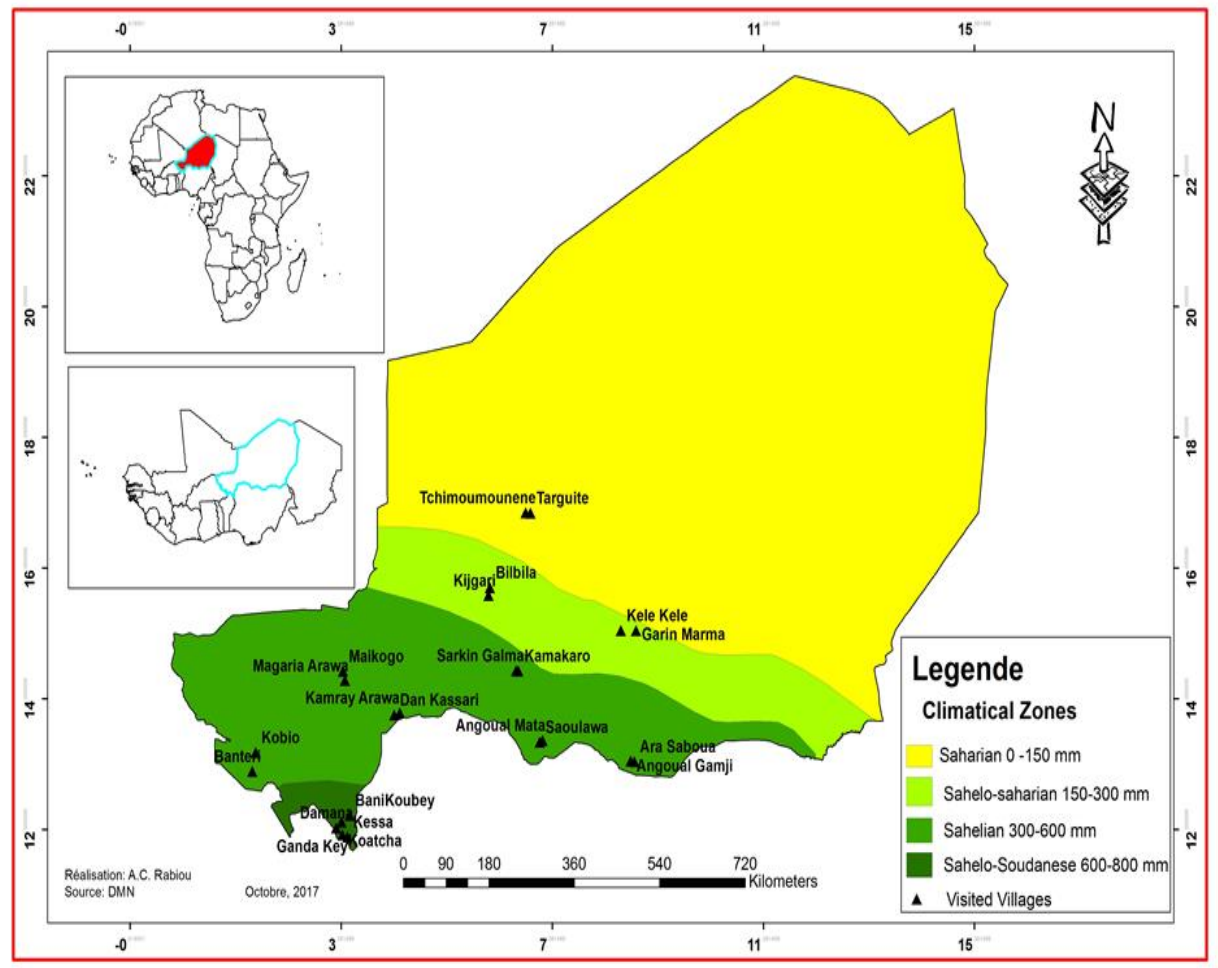

Figure 1 Sampling sites spread over different agro-ecological zones of Niger 


\subsection{Observations and measurements made}

Visual characteristics included feather color and distribution, foot coloring, beak coloring, eye color, barb staining, and ridge type.

Biometric data were obtained using body weighing and body measurements generally used for the biometric characterization of poultry $[9,7]$. Measured parameters were live weight, body length, tarsal tour, tarsal length, wing length, barb length and beak length, thoracic perimeter and wingspan (Table 1). For weighing, an electronic scale (range $20 \mathrm{~kg}$, precision $1 \mathrm{~g}$ ) was used. The body measurements were made using a measuring tape graduated in millimeters.

Table 1 Description of the biometric characters used to measure the local chicken of Niger

\begin{tabular}{|l|l|l|}
\hline Variables & Abbreviation & Description \\
\hline Body length $(\mathrm{cm})$ & BL & $\begin{array}{l}\text { distance between the tip of the upper mandible and that of the tail } \\
\text { (without feather) }\end{array}$ \\
\hline Thoracic Perimeter $(\mathrm{cm})$ & TP & $\begin{array}{l}\text { chest circumference taken below the wings and at the projecting } \\
\text { area of the keel bone }\end{array}$ \\
\hline Wing length (cm) & WL & $\begin{array}{l}\text { length of the extended wing from the junction of the humerus to } \\
\text { the spine to the tip of the wing featherless) }\end{array}$ \\
\hline length of Beak (cm) & LBe & $\begin{array}{l}\text { distance between the tip of the upper mandible and the } \\
\text { commissure of the two mandibles }\end{array}$ \\
\hline Length of tarsus (cm) & LT & Length from the joint of the fingers to the articulation of the thigh. \\
\hline Tarsus tour $(\mathrm{cm})$ & TT & circumference of the tarsus \\
\hline Live weight $(\mathrm{g})$ & LW & Gram weight of the chicken \\
\hline barb length $(\mathrm{cm})$ & LBa & Excrescence from under the beak to its end \\
\hline wingspan $(\mathrm{cm})$ & EW & $\begin{array}{l}\text { Length between the tips of the right and left wings after both are } \\
\text { stretched completely }\end{array}$ \\
\hline
\end{tabular}

\subsection{Ethical Statement}

The National Committee of Ethics on Health Research authorized us to collect this data (authorization No.010 / 2017 / CNERS).

\subsection{Data processing and analysis}

The morphological data were processed with the SPSS software (Statistical Package for the Social Sciences) version 20. The analysis of variance was done with the R software according to the fixed linear factor model with 3 factors (ANOVA) according to sex, local ecotype and agro ecological zones. The R software was used for Spearman's descriptive analyzes and correlation measurements on biometric variables.

\section{Results}

\subsection{Morphological characterization of the local chicken of Niger}

A normal distribution of the feathers predominant within the populations of local chicken of Niger with $96.6 \%$. Nevertheless, 4 other types of plumage distribution were identified. They included crested, frizzle, and feathered tarsi (Table 2) with respective frequencies of $1.8,0.7,0.5$ and $0.4 \%$. An important diversity of plumage colorations was also observed. Out of the thirteen (13) different plumage observed, the most frequent were red (13.5\%), pebbles (12.1\%), white $(11.9 \%)$, golden partridge (11.2\%) and the fawn (10.8\%). The other colours Mille fleur, Silver Partridge, Silver Cuckoo, Splash, Black, Golden Cuckoo, Black whith Golden Camail and Golden Salmon all have frequencies below 10\% (Table 2, Figure 2). Cases of polydactyl were rarely observed, and individuals carrying polydactyly represent only $0.2 \%$ of the total sample. The tarsi were mainly white (45.1\%), grey (39.0\%) and yellow (15.3\%). With a few exceptions, the presence of normal ridges was observed on almost all individuals (99.5\%, Table 3). The two barbel colors observed were red (which ranges from light red to dark red) for nearly 95\% of individuals and black (around 5\%). As for the eyes, they are predominantly orange $(55.1 \%)$ followed by yellow and red with respectively $31 \%$ and $12.1 \%$ (Table 4 ). The beaks are grey on a little over $40 \%$ of the population, horny for $27.1 \%$ of individuals, white for $17,1 \%$ and yellow for $15.5 \%$ (Table 5). 
Table 2 Types of plumage distribution and plumage colors

\begin{tabular}{|c|c|c|c|}
\hline Parameters & Modalities & Size & Frequencies (\%) \\
\hline \multirow{6}{*}{$\begin{array}{l}\text { Types of plumage } \\
\text { distribution }\end{array}$} & Normal & 535 & 96,6 \\
\hline & Naked neck & 4 & 0,7 \\
\hline & Frizzle & 3 & 0,5 \\
\hline & Crested & 10 & 1,8 \\
\hline & Feathered tarsi & 2 & 0,4 \\
\hline & Total & 554 & 100,0 \\
\hline \multirow{14}{*}{ Pulmage color } & White & 66 & 11,9 \\
\hline & Red & 75 & 13,5 \\
\hline & Mille fleur & 46 & 8,3 \\
\hline & Golden Partridge & 62 & 11,2 \\
\hline & Silver cuckoo & 31 & 5,6 \\
\hline & Black & 28 & 5,1 \\
\hline & Mottled & 67 & 12,1 \\
\hline & Splash & 31 & 5,6 \\
\hline & Golden cuckoo & 19 & 3,4 \\
\hline & Black with golden caimail & 20 & 3,6 \\
\hline & Silver Partridge & 40 & 7,2 \\
\hline & Fawn & 60 & 10,8 \\
\hline & Golden samon & 9 & 1,6 \\
\hline & Total & 554 & 100,0 \\
\hline
\end{tabular}

Table 3 Presence / absence of polydactyly and tarsi color

\begin{tabular}{|l|l|l|l|}
\hline Parameters & Modalities & Size & Frequencies (\%) \\
\hline \multirow{4}{*}{ Presence of polydactyly } & Normal & 553 & 99.8 \\
\cline { 2 - 4 } & 5 fingers & 1 & 0.2 \\
\cline { 2 - 4 } & Total & 554 & 100.0 \\
\hline \multirow{5}{*}{ Tarsi color } & White & 250 & 45.1 \\
\cline { 2 - 4 } & Yellow & 85 & 15.3 \\
\cline { 2 - 4 } & Grey & 216 & 39.0 \\
\cline { 2 - 4 } & Brown & 3 & 0.5 \\
\cline { 2 - 4 } & Total & 554 & 100.0 \\
\hline
\end{tabular}

Table 4 Colors of the eyes and the barbell

\begin{tabular}{|l|l|l|l|}
\hline Parameters & Modalities & Size & Frequencies (\%) \\
\hline \multirow{5}{*}{ Eyes color } & Orange & 305 & 55.1 \\
\cline { 2 - 4 } & Yellow & 172 & 31.0 \\
\cline { 2 - 4 } & Red & 67 & 12.1 \\
\cline { 2 - 4 } & Black & 10 & 1.8 \\
\cline { 2 - 4 } & Total & 554 & 100.0 \\
\hline \multirow{5}{*}{ Barbel Color } & Red & 443 & 80.0 \\
\cline { 2 - 4 } & Red-white & 57 & 10.3 \\
\cline { 2 - 4 } & Black & 25 & 4.5 \\
\cline { 2 - 4 } & Dark red & 29 & 5.2 \\
\cline { 2 - 4 } & Total & 554 & 100.0 \\
\hline
\end{tabular}


Table 5 Comb types and beak color

\begin{tabular}{|l|l|l|l|}
\hline Parameters & Modalities & Size & Frequencies (\%) \\
\hline \multirow{4}{*}{ Comb types } & Normal & 551 & 99.5 \\
\cline { 2 - 4 } & Rosea & 3 & 0.5 \\
\cline { 2 - 4 } & Total & 554 & 100.0 \\
\hline \multirow{5}{*}{ Beak color } & Blanc & 95 & 17.1 \\
\cline { 2 - 4 } & corne & 150 & 27.1 \\
\cline { 2 - 4 } & Jaune & 86 & 15.5 \\
\cline { 2 - 4 } & Grey & 223 & 40.3 \\
\cline { 2 - 4 } & Total & 554 & 100.0 \\
\hline
\end{tabular}

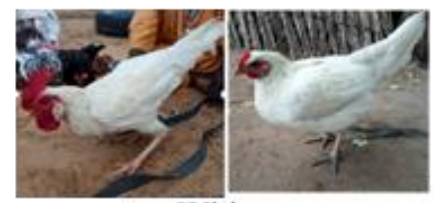

a. White

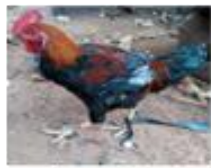

d. Golden samon

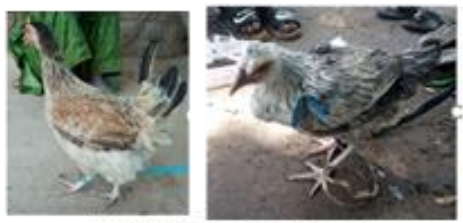

g. Silver Partridge

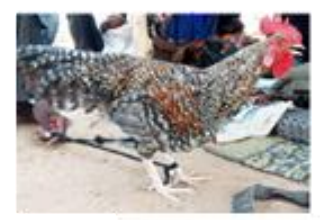

j. Golden cuckoo
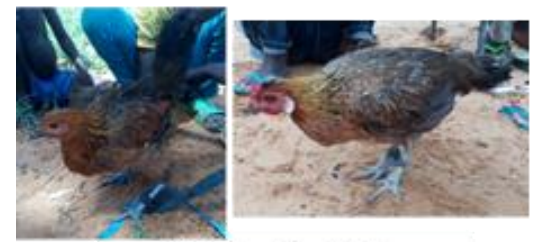

m. Golden Partridge

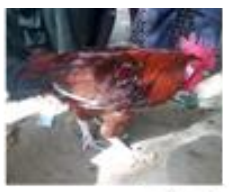

b. Red
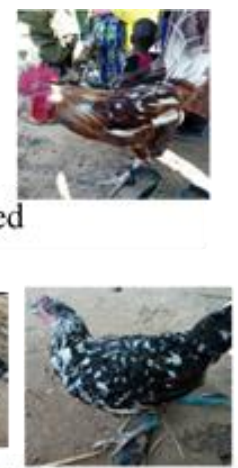

e. Mottled
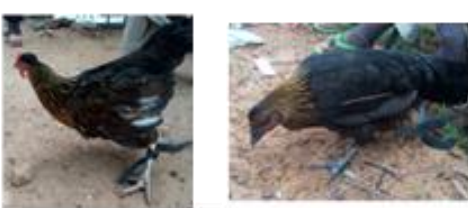

h. Black with golden caimail
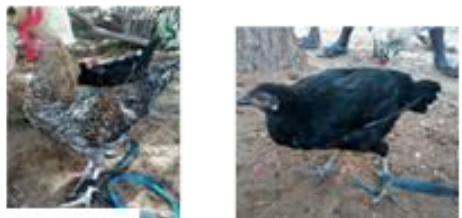

k. Black

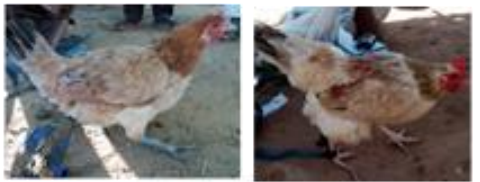

c. Fown
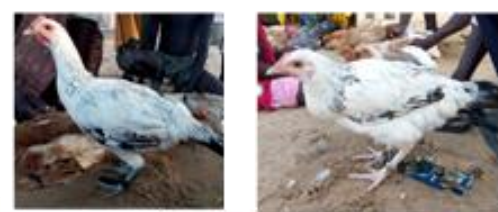

f. splash
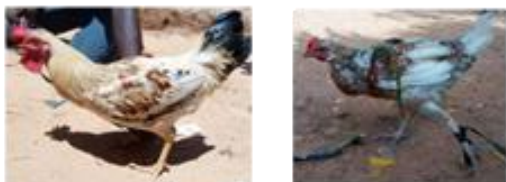

i. Mille fleur
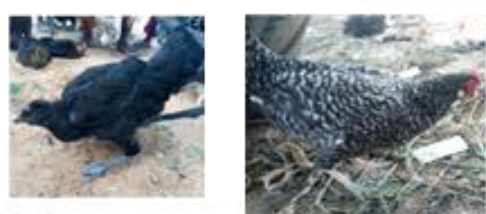

1. Silver cuckoo
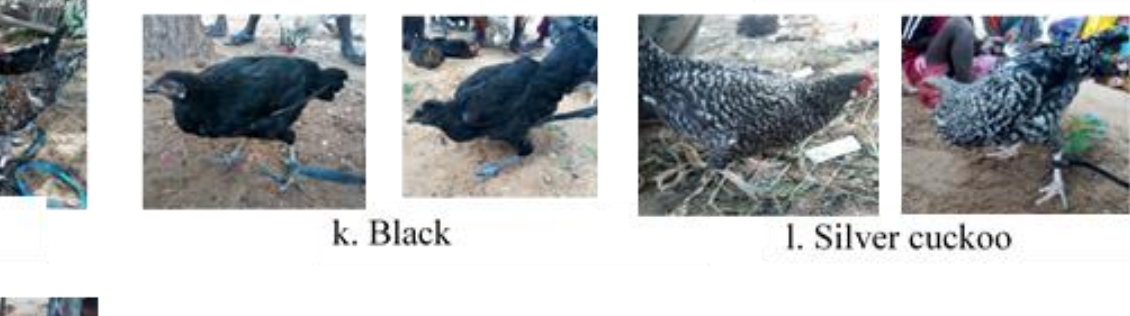

Figure 2 Different colors of plumage observed in Nigerien's local chickens

\subsection{Biometric characterization of the local chicken of Niger}

\subsubsection{Description of the sample}

The average weight obtained on the total sample of 554 individuals of the local chicken of Niger, was $1141,24 \mathrm{~g}$ with a standard error of 12.74 . The average length of the tarsi, the body and wingspan were respectively $8.13 \mathrm{~cm}, 36.50 \mathrm{~cm}$ and $42.49 \mathrm{~cm}$. (Table 6) 
Table 6 Summary of the different parameters measured

\begin{tabular}{|l|l|l|l|l|l|}
\hline Variables & Effective & Minimum & Maximum & Average & Standard error \\
\hline PV $(\mathrm{g})$ & 554 & 515 & 2535 & 1141.24 & 12.74 \\
\hline LT $(\mathrm{cm})$ & 554 & 5.40 & 11.50 & 8.13 & 0.04 \\
\hline LC $(\mathrm{cm})$ & 554 & 22.20 & 48 & 36.50 & 0.13 \\
\hline PT $(\mathrm{cm})$ & 554 & 7.20 & 37.80 & 28.16 & 0.12 \\
\hline TT $(\mathrm{cm})$ & 554 & 2.60 & 5.70 & 3.53 & 0.02 \\
\hline LA $(\mathrm{cm})$ & 554 & 15 & 27.50 & 17.66 & 0.07 \\
\hline LBa $(\mathrm{cm})$ & 554 & 0.10 & 6 & 1.50 & 0.05 \\
\hline LBe $(\mathrm{cm})$ & 554 & 1.50 & 12.70 & 2.92 & 0.02 \\
\hline EA $(\mathrm{cm})$ & 554 & 30.50 & 55.30 & 42.49 & 0.16 \\
\hline
\end{tabular}

PV = live weight; $\mathrm{LT}=$ Tarsus length LC = length of the body; PT = Thoracic Perimeter; TT = Tarsus Tower; $\mathrm{LA}=$ Length of the Wing; $\mathrm{LBa}=\mathrm{Length}$ of the Barbillon; $\mathrm{LBe}=$ Length of the spout; EA = Wingspan

On the basis of information received from producers, the local chicken population in Niger is subdivided into 6 ecotypes (Figure 3)

- The Dourgou ecotype: it is a dwarf chicken very rarely encountered in the local chicken population in Niger.

- The Goggori ecotype: especially encountered in the Sahelian zone, particularly in the south of Maradi (Madarounfa) region, it is characterized by the absence of tail.

- The Gouzou-gouzou ecotype: it is a type of frizzle chicken ecotype that is also rared. Few individuals were mostly met in the Sahelian and Sahelo-Sudanian zone.

- Kolonto ecotype: this chicken is characterized by its large size and rapid growth. It is found mainly in the SaheloSudanian and Sahelian zone.

- The Tchagara ecotype: it is characterized by its small and large laying capacity. It is more met in the Sudanian zone.

- The popular ecotype: this ecotype is of medium size. It represents the largest proportion of the local chicken population in Niger (411 out of 554 total individuals in the sample). She does not have a specific local name. But because it is found in all the agro-ecological zones of Niger, we named it a popular ecotype.
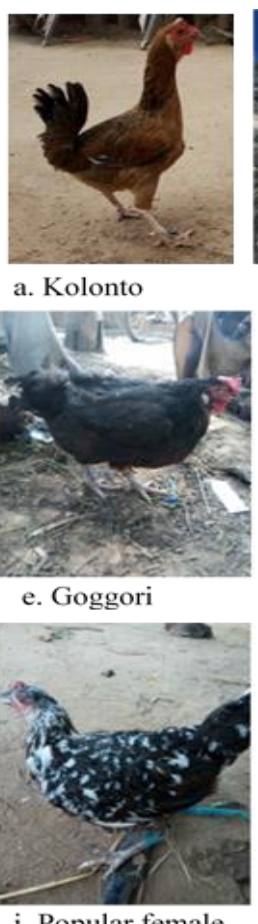

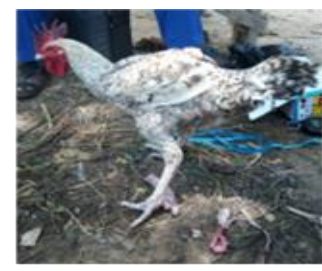

b. Kolonto male

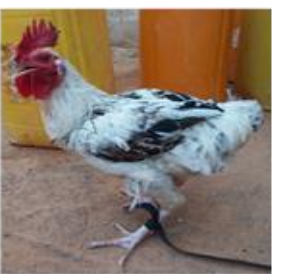

f. Goggori male

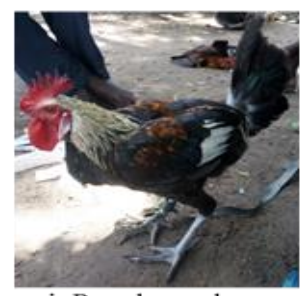

j. Popular male

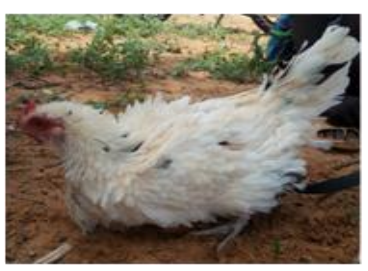

c. Gouzou-gouzou

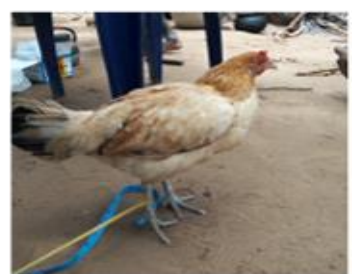

g. Tchagara female

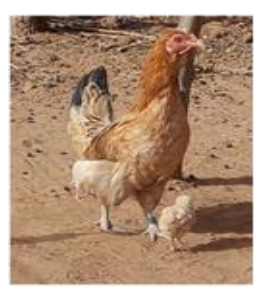

k. Dourgou female

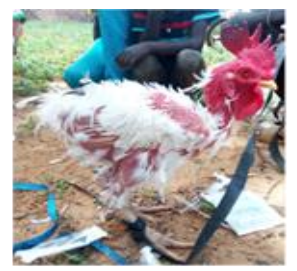

d. Gouzou-gouzou

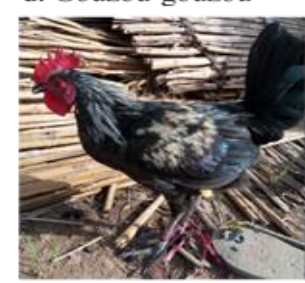

h. Tchagara male

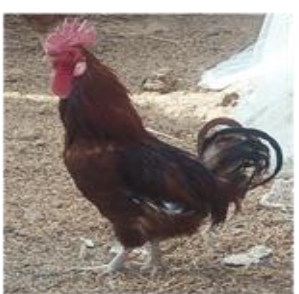

1. Dourgou male

Figure 3 The different ecotypes of local chicken in Niger 


\subsubsection{Biometric variation in population of the local chicken in Niger}

\section{According to sex}

The analysis of variance (ANOVA) with sex as the source of variance showed highly significant differences $(\mathrm{P}$ value $=$ 0.000 ) between the roosters and hens for all the characters studied. For live weight, the roosters mean weight exceeds the hens one by more than $220 \mathrm{~g}$ and tarsi were significantly longer than female one (Table 7 ). This superiority of the values found on males compared to those obtained on females was observed for all the variables studied (Table 7).

Table 7 Mean values by sex, various parameters measured

\begin{tabular}{|c|c|c|c|c|}
\hline \multirow{2}{*}{$\begin{array}{l}\text { Variables } \\
\text { mesurées }\end{array}$} & $\begin{array}{l}\text { Roosters } \\
(\mathrm{N}=156)\end{array}$ & $\begin{array}{l}\text { Hens } \\
(N=398)\end{array}$ & \multirow[t]{2}{*}{ F. val } & \multirow[t]{2}{*}{$\operatorname{Pr}(>F)$} \\
\hline & $\overline{\mathbf{X}} \pm \mathbf{E S}$ & $\overline{\mathbf{X}} \pm \mathbf{E S}$ & & \\
\hline $\mathrm{PV}(\mathrm{g})$ & $1484.24 \pm 45.86^{\mathrm{a}}$ & $1266,64 \pm 45,05^{b}$ & 73.39 & $0.000^{* * *}$ \\
\hline $\mathrm{LT}(\mathrm{cm})$ & $9.22 \pm 0.10^{\mathrm{a}}$ & $7.70 \pm 0.10^{b}$ & 778.25 & $0.000^{* * *}$ \\
\hline $\mathrm{LC}(\mathrm{cm})$ & $40.30 \pm 0.44^{a}$ & $37.21 \pm 0.43^{\mathrm{b}}$ & 157.87 & $0.000^{* * *}$ \\
\hline PT $(\mathrm{cm})$ & $30.63 \pm 0.47^{\mathrm{a}}$ & $29.28 \pm 0.46^{b}$ & 26.96 & $0.000^{* * *}$ \\
\hline $\mathrm{TT}(\mathrm{cm})$ & $4.19 \pm 0.07^{a}$ & $3.69 \pm 0.07^{b}$ & 175.17 & $0.000^{* * *}$ \\
\hline $\mathrm{LA}(\mathrm{cm})$ & $19.36 \pm 0.22^{\mathrm{a}}$ & $17.18 \pm 0.22^{b}$ & 310.23 & $0.000^{* * *}$ \\
\hline $\mathrm{LBa}(\mathrm{cm})$ & $3.38 \pm 0.13^{\mathrm{a}}$ & $1.25 \pm 0.13^{\mathrm{b}}$ & 857.83 & $0.000^{* * *}$ \\
\hline $\mathrm{LBe}(\mathrm{cm})$ & $3.07 \pm 0.09^{a}$ & $2.93 \pm 0.09 \mathrm{~b}$ & 6.84 & $0.009 * *$ \\
\hline $\mathrm{EA}(\mathrm{cm})$ & $46.34 \pm 0.46^{a}$ & $41.44 \pm 0.45^{b}$ & 365.43 & $0.000^{* * *}$ \\
\hline
\end{tabular}

a, b: on the same line, the same letter is given to the values showing no statistically significant difference between them at risk alpha $=0.05 ;{ }^{*}=$ significant; ${ }^{* *}=$ very significant; ${ }^{* * *}=$ highly significant, $\mathrm{N}=$ effective; $\overline{\mathrm{X}}=$ adjusted average; $\mathrm{ES}=\mathrm{Standard}$ error; $\mathrm{PV}=$ live weight; $\mathrm{LT}=\mathrm{Tarsus}$ length; LC = length of the body; PT = Thoracic Perimeter; TT = Tarsus Tower; LA = Length of the Wing; LBa = Length of the Barbillon; LBe = Length of the spout; EA = Wingspan; F.val = Fisher's test value

\section{According to agro ecological zones}

Analysis of variance (ANOVA) with agroecological zones as a source of variation between the population of the Sahelian, Saharan, Sahelo-Saharan and Sahelo-Sudanian zones showed significant differences ( $\mathrm{P}$ value $=0.031)$, very significant $(\mathrm{P}$ value $=0.003)$ and highly significant $(\mathrm{P}$ value $=0.003)$ with the variables live weight, body length and tarsal length, respectively. for live weight, the Sahelian and Saharan zone average of $1387.33 \mathrm{~g}$ and $1458.77 \mathrm{~g}$, respectively, is higher than that of the Sahelo-Saharan zone and the Sahelo-Sudanian zone, which were respectively 1375.09g and 1280.58g. For the length of the tarsi, the local chicken of the Sahelo-Sudanian and Sahelo-Saharan zone have tarsi of $8.57 \mathrm{~cm}$, longer than those of the Sahelian and Saharan zone which are respectively $8.28 \mathrm{~cm}$ and $8.43 \mathrm{~cm}$. Regarding the average length of the body, the chicken of the Sahelo-Saharan zone has a value $39.46 \mathrm{~cm}$ higher than those obtained in the SaheloSudanese, Saharan and Sahelian zones which are respectively $38.71 \mathrm{~cm}, 38.58 \mathrm{~cm}$ and $38.27 \mathrm{~cm}$. Of the variables measured, only 3 variables (live weight, tarsal length and body length) make it possible to differentiate chicken according to agro-ecological zones.

\section{According to the ecotypes}

Analysis of variance (ANOVA) based on the local chickens' ecotypes found in Niger showed that it is only the beak length where the difference is the Kolonto with an average weight of $1454.17 \mathrm{~g}$ are the ecotypes with the highest live weight. They are followed by the Gouzou-gouzou and Dourgou ecotypes with successive weights of 1388.31g and 1378.31g. Finally, the less heavy chicken ecotypes in Niger are the Popular and Tchagara with average weights not significant (table 8). For the variable live weight, the Goggori with an average weight of $1521.40 \mathrm{~g}$ and of $1160.69 \mathrm{~g}$ and $1084.01 \mathrm{~g}$ respectively (Table 8 ). 
Table 8 Mean values of the different parameters measured, reflecting the morphological differences between the local chicken ecotype of Niger

\begin{tabular}{|c|c|c|c|c|c|c|c|c|}
\hline \multirow{2}{*}{$\begin{array}{l}\text { Variables } \\
\text { mesurées }\end{array}$} & $\begin{array}{l}\text { Kolonto } \\
(\mathrm{N}=46)\end{array}$ & $\begin{array}{l}\text { Goggori } \\
(\mathrm{N}=10)\end{array}$ & $\begin{array}{l}\text { Tchagara } \\
\text { (79) }\end{array}$ & $\begin{array}{l}\text { Gouzou-gouzou } \\
(\mathrm{N}=3)\end{array}$ & $\begin{array}{l}\text { Dourgou } \\
(\mathrm{N}=3)\end{array}$ & $\begin{array}{l}\text { Populaire } \\
(413)\end{array}$ & \multirow[t]{2}{*}{ F.val } & \multirow[t]{2}{*}{$\operatorname{Pr}(>F)$} \\
\hline & $\overline{\mathbf{X}} \pm \mathrm{ES}$ & $\overline{\mathrm{X}} \pm \mathrm{ES}$ & $\overline{\mathbf{X}} \pm \mathrm{ES}$ & $\overline{\mathrm{X}} \pm \mathrm{ES}$ & $\overline{\mathbf{X}} \pm \mathbf{E S}$ & $\overline{\mathbf{X}} \pm \mathbf{E S}$ & & \\
\hline PV (g) & $1454.17 \pm 63.40^{b}$ & $1521.40 \pm 84.58^{b}$ & $1084.01 \pm 64.03^{\mathrm{a}}$ & $1388.31 \pm 149.20^{\mathrm{ab}}$ & $1378.31 \pm 149.20^{\mathrm{ab}}$ & $1160.69 \pm 22.33^{a}$ & 10.85 & $0.000^{* * *}$ \\
\hline $\mathrm{LT}(\mathrm{cm})$ & $9.58 \pm 0,13^{c}$ & $8.80 \pm 0,17^{b}$ & $8.19 \pm 0,13^{b}$ & $8,89 \pm 0,31^{b c}$ & $6.62 \pm 0,31^{\mathrm{a}}$ & $8.47 \pm 0,05^{b}$ & 30.14 & $0.000^{* * *}$ \\
\hline $\mathrm{LC}(\mathrm{cm})$ & $40.22 \pm 0.63^{c}$ & $40.04 \pm 0,84 \mathrm{bc}$ & $36.92 \pm 0,64^{\mathrm{ab}}$ & $38.50 \pm 1.48 \mathrm{abc}$ & $38.99 \pm 1,48^{\mathrm{abc}}$ & $37.09 \pm 0,22^{\mathrm{a}}$ & 8.83 & $0.000^{* * *}$ \\
\hline $\mathrm{PT}(\mathrm{cm})$ & $31 \cdot 12 \pm 0,67^{c}$ & $31 \cdot 17 \pm 0,90^{\mathrm{bc}}$ & $28.00 \pm 0,68^{\mathrm{ab}}$ & $30.28 \pm 1,58^{\mathrm{abc}}$ & $30.61 \pm 1,58^{\mathrm{abc}}$ & $28,00 \pm 0,24^{\mathrm{a}}$ & 8.31 & $0.000^{* * *}$ \\
\hline $\mathrm{TT}(\mathrm{cm})$ & $4.14 \pm 0.09^{b}$ & $3.86 \pm 0.12^{\mathrm{ab}}$ & $3.63 \pm 0.09^{a}$ & $3.92 \pm 0.22^{\mathrm{ab}}$ & $4.05 \pm 0.22^{\mathrm{ab}}$ & $3.58 \pm 0,03^{a}$ & 9.83 & $0.000^{* * *}$ \\
\hline $\mathrm{LA}(\mathrm{cm})$ & $20.11 \pm 0.29^{c}$ & $18.52 \pm 0.39^{b}$ & $18.71 \pm 0.29^{b}$ & $18.39 \pm 0.68^{\mathrm{abc}}$ & $16.25 \pm 0.68^{\mathrm{a}}$ & $17.88 \pm 0.10^{\mathrm{ab}}$ & 12.24 & $0.000^{* * *}$ \\
\hline $\mathrm{LBa}(\mathrm{cm})$ & $2.39 \pm 0.18^{b}$ & $2.36 \pm 0.24^{\mathrm{ab}}$ & $1.71 \pm 0.18^{a}$ & $2.60 \pm 0.43^{\mathrm{ab}}$ & $2.30 \pm 0.43^{\mathrm{ab}}$ & $1.97 \pm 0.06^{\mathrm{ab}}$ & 3.44 & $0.004^{* *}$ \\
\hline $\mathrm{LBe}(\mathrm{cm})$ & $2.93 \pm 0.14^{\mathrm{a}}$ & $2.93 \pm 0.19^{a}$ & $2.69 \pm 0,15^{\mathrm{a}}$ & $2.98 \pm 0.34^{\mathrm{a}}$ & $3.15 \pm 0.34^{\mathrm{a}}$ & $3.01 \pm 0.05$ & 0.95 & 0.445 \\
\hline $\mathrm{EA}(\mathrm{cm})$ & $47.38 \pm 0.62^{\mathrm{b}}$ & $45.65 \pm 0.83^{\mathrm{ab}}$ & $42.72 \pm 0.63^{a}$ & $41.41 \pm 1.46^{\mathrm{a}}$ & $41.31 \pm 1.46^{\mathrm{a}}$ & $43.61 \pm 0.22^{\mathrm{a}}$ & 13.25 & $0.000^{* * *}$ \\
\hline
\end{tabular}

a, b, c: on the same line, the same letter is given to the values showing no statistically significant difference between them at risk alpha $=0.05 ;{ }^{*}=$ significant; ${ }^{* *}=$ very significant; ${ }^{* * *}=$ highly significant, $\mathrm{N}=$ effective; $\overline{\mathrm{X}}=$ adjusted average; $\mathrm{ES}=$ Standard error; PV = live weight; LT = Tarsus length; LC = length of the body; PT = Thoracic Perimeter; TT = Tarsus Tower; LA = Length of the Wing; LBa = Length of the Barbillon; LBe = Length of the spout; EA = Wingspan; F.val = Fisher's test value 


\subsubsection{Relationship between the live weight of the chicken and other biometric parameters}

All measured variables are correlated with each other. For values obtained between 0.091 and 1, the variables are positively correlated; this correlation is stronger for values close to 1 . But the values obtained between -1 to -0.091 , the variables are negatively correlated; this correlation is stronger for values close to -1 . Live weight is positively correlated with all studied variables (Figure 4). This correlation is strong with the thoracic perimeter, the length of the body, the tarsal turn and the length of the barbillon. Beak length represents the variable that is less correlated with live weight and other variables.

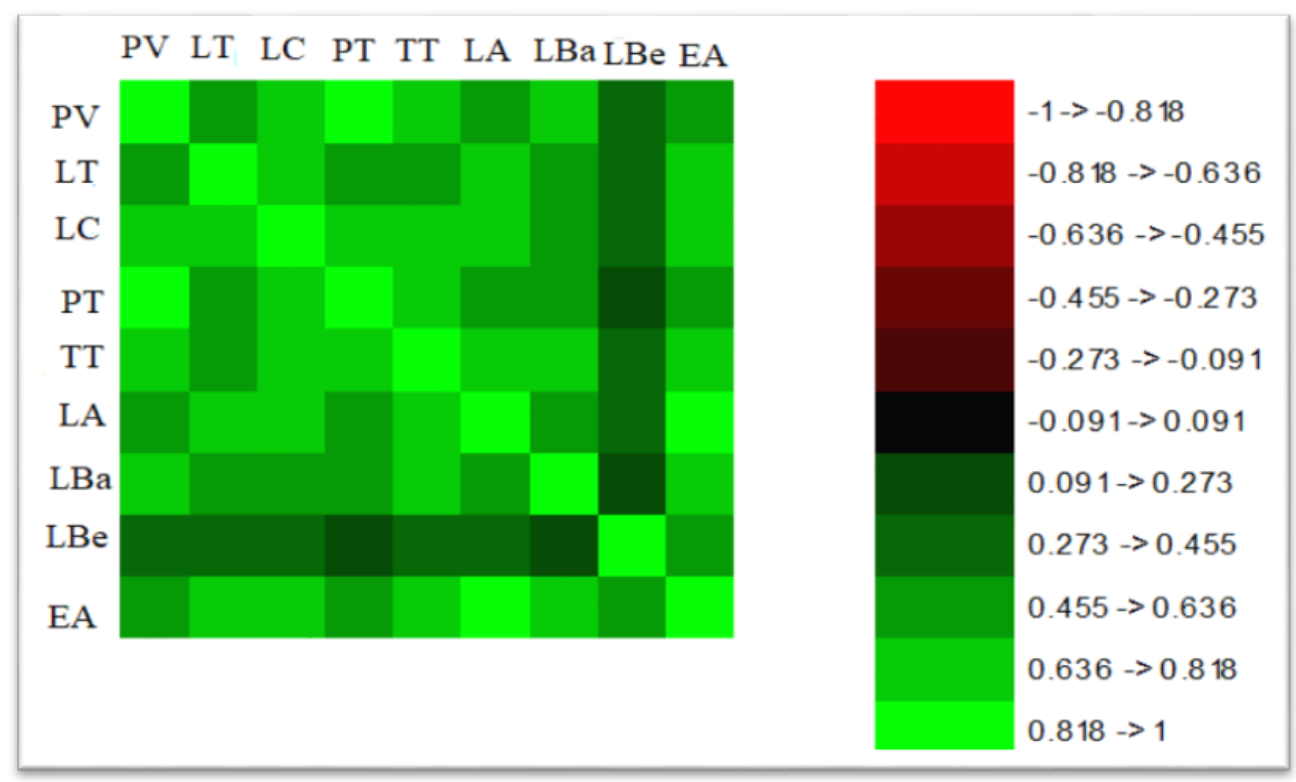

PV = live weight; LT = Tarsus length; $\mathrm{LC}=$ length of the body; PT = Thoracic Perimeter; TT $=$ Tarsus Tower; LA = Length of the Wing; LBa = Length of the Barbillon; LBe = Length of the spout; EA = Wingspan

Figure 4 Spearman correlation image between biometric variables Studied

\subsubsection{Prediction equations for live weight of Niger's local chicken population}

The thoracic perimeter is the variable that helps to predict the live weight of the local chicken in Niger (Table 9). The best prediction equation of this weight is of linear type:

$\mathrm{PV}=86.304 \mathrm{PT}-1289.258 ; \mathrm{R} 2=0.682$

Table 9 Regression between live weight and some biometric parameters

\begin{tabular}{|l|l|l|}
\hline Measurements & Equations & $\mathbf{R}^{\mathbf{2}}$ \\
\hline Thoracic perimeter & $\mathrm{PV}=86.304 \mathrm{PT}-1289.258$ & 0.682 \\
\hline length of the body & $\mathrm{PV}=67.534 \mathrm{LC}-1323.588$ & 0.492 \\
\hline Tarsus Tower & $\mathrm{PV}=475.095 \mathrm{TT}-537.540$ & 0.592 \\
\hline
\end{tabular}

\section{Discussion}

This study aims to determine the characteristics of the local chicken in Niger.

In the first place, the study showed a large phenotypic diversity of local chicken populations in Niger, which confirms the work of Mc Ainsh et al., [10] who considered that phenotypic variation is characteristic of local chickens. This observed phenotypic diversity would also probably reflect the existence of numerous morphological mutations resulting from domestication and non-control breeding [11]. 
There is a great variability of plumage in the local chicken population of Niger. The main colors of plumage encountered in the Niger's' chicken are Red (13.5\%), Pebble (12.1\%), White (11.9\%), Golden Partridge (11.2\%), Fawn (10.8\%) and the Thousand Flowers (8.3\%). The plumage diversity of local chickens has been reported in other studies in several countries. This is the case of Congo Brazzaville by Akouango et al., [12], Benin by Chabi-Toko [13], Cameroon by Fotsa et al., [14] and Keambou et al., [15], Central African Republic by Bembide et al., [16], Côte d'Ivoire by Yapi-Gnaoré et al., [17], South Africa by Van Marle-Koster and Casey [18], and China by Lujiang et al., [19]. The plausible explanation for this diversity is that several genes interacted to determine this multitude of feather coloring [20]. The hypothesis that Oluyemi and Roberts [21] have put forth to explain this feather diversity is that local chickens would not be subject to any artificial selection. For Périquet [22], these colors are due to the existence of major effect genes and interact with many of them. The presence of light colors such as white or cuckoo (silver and gold) in our study, can translate a level of dilution of local genes through the introduction of commercial chicken type [23].

Our study showed that the normal distribution of feathers is more prevalent in the local chicken population in Niger with a proportion of $96.6 \%$. This result is slightly higher than that of El-Safty, [24] in Libya, that of Egahi et al., [25] in Nigeria and that of Dao et al., [26] in Togo which reported respectively a proportion of 87.1\%, 82.05\% and 82\%. Types of feathers such as crested, feathered tarsi, neckless and curly are rare in the local chicken of Niger. Egahi et al., [25] found a proportion of $17.8 \%$ of crested birds in the chicken population in Nigeria. The proportion of naked neck obtained in our study is well below $6 \%$ found by Guèye [3] in Nigeria.

[20] reported that the crested head is due to an incompletely dominant ( $\mathrm{Cr}$ ) gene that causes a tuft of feathers above the head behind the ridges. For the genes responsible for the neck (Na) or Frizzle (F) type, they induce heat tolerance of the chicken $[27,28,29,30]$. In hot conditions, the "naked neck" phenotype is better in meat and egg production than the normal phenotype [26]. This rarity of the naked neck or frizzle phenotype in our study is probably related to some considerations of producers who link their breeding to a fetish character, which exerts a negative selection pressure on these types of chicken in Niger. Sonaiya and Olori [31] reported that producers find their naked neck and frizzle naughty, and therefore, are only raised by older people for occult purposes.

The simple ridge type is more dominant in the chicken population in Niger with a proportion of 99.5\%. This result is consistent with that of Dao et al., [26] in Togo, Bembide [16] in the Central African Republic, Badubi et al., [32] in Botswana, FAO [33] in Bangladesh, Keambou et al., [15] in western Cameroon, Wani [34] in Sudan, Moges et al., [35] in Ethiopia and Apuno et al., [36] in Nigeria. In contrast to our finding, Nigussie et al., [37] reported that the pitch ridge is the most common in the local chicken population in the Farta, Mandura, Horro, Konso and Sheka areas of Ethiopia. Crawford [20] has stated that the type of crest type inheritance in chickens is due to two pairs of genes carried by autosomes (Rose, RR and pitch ridge, PP), so the simple crest type is a recessive type. (rrpp).

The "polydactyl" phenotype encountered in this study has a frequency of $0.2 \%$. This phenotype is significantly lower than that reported by Akinokun [38] and Ikeobi et al., [39], who respectively found a frequency of 10\% and 8\% of this "polydactyl" phenotype in Nigeria. The orange coloring of the eyes is the most predominant in the local chicken population of Niger with a proportion of 55.1\%. It is the same in Togo [26] and in the plateau region of Nigeria Mancha [40].

The tarsi of white, black and yellow are respectively the most predominant with respective values of $45.1 \%, 31 \%$ and 12.1\%. El-Safty, [24] in Libya found that black tarsi (39.9\%) are the most common, followed by yellow (24.5\%), blue (18.7\%) and white (17.9\%). For Dao et al., [26] in Togo, he found that chicken tarsi are white (34\%), yellow (30\%), gray $(26.83 \%)$ and black (9.17\%). The yellow color found in our study would result from the introduction of exotic breeds. In fact, the presence of the $\mathrm{W}$ mutation that causes a xanthophyll pigment deposit in the epidermis of the skin and tarsi [41] comes from commercial lines introduced in traditional farms [42,43].

On the basis of knowledge of the producers of the local chicken of Niger, we identified the existence of 6 ecotypes namely: Tchagara, Goggori, Gouzou-gouzou, Dourgou, Popular and Kolonto. This last ecotype has already been described by Moussa et al., [44] as a large strain which he nicknamed the traditional broiler chicken. The Goggori ecotype also has a character of flesh production because of its high weight. Thus, the breeding of the Kolonto and Goggori strain can be encouraged for the production of flesh while that of the Tchagara strain can be encouraged for the production of eggs. In order to fight against poverty, it is very important to popularize the breeding of Kolonto, Goggori and Tchagara ecotypes because of their productive specificity. The ecotype Gouzou-gouzou is not liked by the producers of the local chicken of Niger because of certain consideration. Thus its popularization will not be a success despite being a strain adapted to the warm environment. The popular ecotype has no specific characteristic. Because it presents intermediate characters between the other ecotype, we think that it would be the result of multiple interbreeding between the different strains of local chicken of Niger. 
The study found a sexual dimorphism within the local chicken populations studied and this on all the measured variables. Sexual dimorphism is not a new phenomenon in poultry and particularly in chickens where roosters are morphologically different from hens $[45,3,46,47,48,49]$. The roosters of Niger with an average weight of $1484.24 \mathrm{~g}$, are heavier than hens with an average weight of $1266.64 \mathrm{~g}$. The values of the average weight of roosters and hens obtained are lower than those found by Hassaballah et al., [50] in Tchad, but higher than those found by Youssao et al., [42] in Benin. Sexual dimorphism shows that a breeding program for chicken meat production would be more beneficial with roosters [51].

The average thoracic perimeter obtained in this study is $28.16 \mathrm{~cm}$. It is intermediate between that found by Guni et al., [52] in Tanzania (24.3 to $26.6 \mathrm{~cm}$ ) and that obtained by Keambou et al., [15] in the highlands of Cameroon (39.1 cm). The length of tarsus obtained is lower than that of chicken in the forest zone of Cameroon [53] which is $9.1 \mathrm{~cm}$.

This study showed positive and significant correlations $(\mathrm{P}=0.001)$ between body weight and body measurements. This type of correlation was also found by Mancha [40] and Sudik [54] on local chicken individuals in Nigeria, which shows that these traits can be used in animal production in predicting chicken weight $[55,3,56]$.

\section{Conclusion}

The main characteristic identified by this study on local chicken populations in Niger is its large phenotypic diversity which is due to the chicken production system. The different morpho-biometric parameters observed and measured also show that the local chicken of Niger still has its natural character and a potential exploitable by possible future programs of improvement of the poultry sector in particular and animal program in general. And, to get there, investigations on the local chicken of Niger must continue in particular on zootechnical and genetic performances.

\section{Compliance with ethical standards}

\section{Acknowledgments}

The authors would like to thank the National Institute of Agronomic Research of Niger and Regional Center Specialized in breeding (CRS/EL) for having funded the data collection of this work, the National Committee of Ethics on Health Research for having authorized us to collect this data (authorization No.010/2017/CNERS), the various departmental and communal livestock services for valuable assistance in the selection of villages and in the conduct of investigations.

\section{Disclosure of conflict of interest}

All authors declare no conflict of interest in this study.

\section{Statement of ethical approval}

The National Committee of Ethics on Health Research authorized us to collect this data (authorization No.010 / 2017 / CNERS)

\section{References}

[1] Kperegbeyi JI, Meye JA, Ogboi E. Local chicken production: strategy of household poultry development in coastal regions of Niger Delta, Nigeria. African Journal of General Agriculture. 2009; 5(1) : 17-20.

[2] Sonaiya EB, Swan SEJ. Production en aviculture familiale. Manuel FAO de Production et Santé Animales. Un manuel technique. Ed. FAO, Rome. 2004.

[3] Guèye EF. Village egg and fowl meat production in Africa. World's Poult. Sci. J. 1998; 54: 73-86.

[4] Guèye EF. Gender issues in family poultry production systems in low-income food-deficit countries. American Journal of Alternative Agriculture. 2003; 18(4): 185-195.

[5] RGAC. Analyse des résultats des enquêtes sur les marchés à bétail et le cheptel aviaire. Recensement général de l'agriculture et du cheptel 2005-2007.

[6] Amadou Moussa B, Idi A. Benabdeljelil K. Aviculture familiale rurale au Niger : alimentation et performances zootechniques. RIDAF. 2010; 19(1): 5-12. 
[7] FAO. Phenotypic characterization of animal genetic resources. FAO Animal Production and Health Guidelines. 2012.

[8] République du Niger. Programme d'Action National d'Adaptation aux changements climatique. $2006 ; 90$.

[9] Moula N, Antoine-Moussiaux N, Farnir F, Detilleux J, Leroy P. Réhabilitation socioéconomique d'une poule locale en voie d'extinction : la poule Kabyle (Thayazit lekvayel). 2009; 9.

[10] McAinsh CV, Kusina J, Madsen J, Nyoni O. Traditional chicken production in Zimbabwe. Worlds Poultry Science Journal. 2004; 60: 233 - 246.

[11] Mahammi FZ, Gaouar SBS, Tabet-Aoul N, Tixier- Boichard M, Saïdi-Mehtar N. Caractéristiques morphobiométriques et systèmes d'élevage des poules locales en Algérie occidentale (Oranie). Cah Agric. 2014; 23 : 1-11.

[12] Akouango F, Mouangou F. et Ganongo, G. Phénotypes et performances d'élevage chez les populations locales de volailles du genre Gallus gallus au Congo Brazzaville. Cahiers Agricultures. 2004; 257-262.

[13] Chabi -Toko. Caractérisation phénotypique et gestion de la population de poulets locaux dans les communes de Dassa et de Toffo au Bénin. Mémoire du Diplôme d'Etudes Approfondies (DEA), Université d'Abomey-Calavi. 2008; 74.

[14] Fotsa JC, et Manjeli Y. Caractérisation phénotypique des populations de poules locales (Gallus Gallus) de la zone forestière dense humide à pluviométrie bimodale du Cameroun. Annales des Sciences Agronomiques du Bénin. 2010; 2(2): 181-192.

[15] Keambou TC, Manjeli Y, Tchoumboue J, Teguia A et Iroume RN. Caractérisation morpho biométrique des ressources génétiques de poules locales des hautes terres de l'ouest Cameroun. Livestock Research for Rural Development. 4 August 2014; 19(107).

[16] Bembide C, Hako - Touko BA, Manjeli Y, et Keambou, Tiambo C. Caractérisation morpho biométrique de la poule locale en Centrafrique. Animal Genetic Ressources. 2013; 53: 33-44.

[17] Yapi-Gnaore CV, Loukou NE, N'Guetta ASP, Kayang B, Xavier Rognon X, Tixier-Boichard M, Touré G, Coulibaly Y et Youssao I. Diversité phénotypique et morphométrique des poulets locaux (Gallus gallus) de deux zones agroécologique de Côte d'Ivoire. Cah Agric. novembre-décembre 2010; 19(6).

[18] Van Marle-Koster E, Casey NH. Phenotypic characterization of native chicken lines in South Africa. Anim Genet Resour Inf. 2001; 29: 71-8.

[19] Lujiang Q, Li X, Xu G, et al. Evaluation of genetic diversity in Chinese indigenous chicken breeds using microsatellite markers. Sci China Ser C. 2006; 49: 305-8.

[20] Crawford RD. Poultry Breeding and Genetics. Elsevier, Amsterdam. 1990.

[21] Oluyemi JA, Roberts FA. In: poultry production in warm and wet climates. Edited by Oluyemi J. A. and Roberts, F. A. The Macmillan Press Ltd. London and Basingstoke. 1979.

[22] Périquet JC. La poule : race, condition d'élevage, Hygiène et santé produits. Les cahiers d'élevage, ed Rustica. 1997; 112.

[23] Juarez CA, Manriquez AJ Ay, Segura CJC. Rasgos de apparencia fenotipica en la aviculture rural de los municipos de la ribera del lago Patzcuaro, Michoacan, Mexico. Livestock research for rural development. 2000; 12(1).

[24] El-Safty SA. Determination of some quantitative and qualitative traits in Libyan native fowls. Egypt. Poult. Sci. 2012; 32(II): 247-258.

[25] Egahi JO, Dim NI, Momoh OM, Gwaza DS. Variations in qualitative traits in the Nigerian local chicken. International Journal of Poultry Science. 2010; 9 : 978-979.

[26] Dao B, Kossoga A, Lombo Y, Ekoué S, Talaki E, Dayo GK, Bonfoh B. Caractérisation phénotypique des populations locales de poulets (gallus gallus domesticus) au Togo. Bull. Anim. Hlth. Prod. Afr. AnGR Special Edition. 2015; 1533.

[27] Al-Rawi AA et Al-Athari AK. Characteristics of indigenous chickens in Iraq. Animal Genetic Resources Information. 2002; 32: 87-93.

[28] Merat P. Potential usefulnsess of the Na (naked neck) gene in poultry production. Wold's Poultry Science Jounal. 1986; 42: 124-142. 
[29] Horst P. Native fowls as reservoir for genomes and major genes with direct and indirect effect on the adaptability and their potential for tropically oriented breeding plans. Archiv für Geflügelkunde. 1989; 53(3): 93-101.

[30] Hako Touko BA. Paramètres zootechniques, hématologiques et thermo-tolérance de quatre types génétiques de la poule locale (Gallus gallus) des Hautes Terres de l'ouest Cameroun. Thèse de master of science, FASA, Dschang, Cameroun. 2008; 70.

[31] Sonaiya EB, et Olori VE. Village chicken production in South-Western Nigeria. In: In E.B. Sonaiya (ed.) Rural Poultry in Africa-Proceedings of an International Conference on Rural Poultry Production. Thelia house, OAU. $1990 ; 243-247$.

[32] Badubi SS, Rakereng M, et Marumo M. Morphological characteristics and feed resources available for indigenous chickens in Botswana. CIPAV, Columbia. Livestock Research for Rural Development. 3 may 2013; 18(3).

[33] FAO. Animal Genetic Resource information. Food and Agriculture Organization of United Nation. $2005 ; 76-81$.

[34] Wani CE. Genetic and phenotypic characterisation of the Sudanese indigenous chicken using molecular biology techniques. PhD thesis, Faculty of Animal Production, University of Khartoum. 2008.

[35] Moges F, Melesse A, et Dessie T. Assessment of village chicken production system and evaluation of the productive and the reproductive performance of the local ecotype in Bure district, North West Ethiopia. Afr. J. Agric. Res. 2010; 5(13): 1739-1748.

[36] AA Apuno, MbapST, T. Ibrahim. Characterization of local chickens (Gallus gallus domesticus) in Shelleng and Song Local Government Areas of Adamawa State, Nigeria. Agriculture and Biology Journal of North America.

[37] Nigussie D, Tadelle D, Liesbeth H, van der Waaij LD. et van Arendonk, J.A.M. Morphological features of indigenous chicken populations in Ethiopia. Animal Genetic Resources. 2010; 46: 11-23.

[38] Akinokun 0. An evaluation of exotic and indigenous chickens as genetic materials for development of rural poultry production in Africa. In E.B. Sonaiya, (ed.) Rural Poultry in Africa: Proceedings of an International Workshop Held in Ile-Ife, Nigeria. 1989; 13-16, pp. 56-69.

[39] Ikeobi CON, Ozoje MO, Adebambo OA, et Adenowo JA. Frequencies of feet feathering and comb type genes in the Nigerian local chicken. In E.B. Sonaiya (ed.) Issues in Family Poultry Research and Development. Proceedings of an International Workshop.1997. 220-224.

[40] Mancha YP. Characterization of local chickens in Northern part of the Jos Plateau. A PhD Thesis, Animal Production Program, School of Agriculture, ATBU, Bauchi. 2004.

[41] Mc Gibbon WH. A shank color mutation in Cornell random bred SCW Leghorns. Poultry Sci. 1974; 53: 1251-3.

[42] Youssao IAK, Tobada PC, Koutinhouin BG, Dahouda M, Idrissou ND, Bonou GA, Tougan UP, Ahounou S, YapiGnaoré V, Kayang B, Rognon X, Tixier-Boichard M. Phenotypic characterization and molecular polymorphism of indigenous poultry populations of the species Gallus gallus of Savannah and Forest ecotypes of Benin. African Journal of Biotechnology. 2010; 9(3): 369-381.

[43] Fotsa JC. Caractérisation des populations de poules locales (gallus gallus) au Cameroun. Mémoire de thèse. 2008; 301.

[44] Moussa Hassan Ousseini, Issa Salissou, Hima Karmadine, Bakasso Yacoubou, Morpho-Biometric Characterization of the "Kolonto" Local Chicken Ecotype in Gaya Area, International Journal of Natural Resource Ecology and Management. 2019; 4(4): 83-88.

[45] Pérez A, Polanco GY, Pérez Y. Algunas caractéristicas morphologicas del extérior de la gallina local de la region central de la provincia de villa clara, Cuba. Livestock research for rural development. 2004.

[46] Mallia JG. The black Maltese: a Mediterranean, light breed of poultry. Animal Genetic Resources Information. 1998; 24: 41-48.

[47] Ngou Ngoupayou JD. Country report on smallholder rural poultry production in Cameroon. In: CTA Seminar Proceedings. Smallholder Rural Poultry Production. Thessalonica, Greece. Oct. 1990; 2: 39-47.

[48] Missohou A, Dieye PN, et Talaki E. Rural poultry production and productivity in Southern Senegal. Livest. Res. Rural Dev. 14. 2002.

[49] Msoffe PLM, Mtambo MMA, Minga UM, Gwakisa P S, Mdegela R H And Olsen J E, (2002). Productivity and natural disease resistance potential of free ranging local chicken ecotypes in Tanzania Livestock Research for Rural Development . 2002; 14 (3). 
[50] Hassaballah KV, Zeuh LY. Mopate et M Sembene. Caractérisation morpho-biométrique de poule (Gallus gallus) locales dans trois zones agro-écologiques du Tchad. Livestock Research for Rural Development. 2015; 27(3).

[51] Mube H K, Yemdjie DDM, Kana JR, Tadondjou CD et Teguia A. Caractérisation phénologiques de la poule barrée de l'ouest Cameroun. Bull. Anim. Hlth. Prod. Afr. 2013; 61: 543-551.

[52] Guni FS, Katule AM Mwakilembe PAA. Characterization of local chickens in selected districts of the Southern Highlands of Tanzania: II. Production and Morphometric traits. Livestock Research for Rural Development. 5 November 2013; 25(190).

[53] Fotsa JC, Bordas A, Rognon X, Tixier-Boichard M, Poné Kamdem D, Manjeli Y. Caractérisation des élevages et des poules locales et comparaison en station de leurs performances à celles d'une souche commerciale de type label au Cameroun. Journée de la Recherche Avicole (Tours). 2007; 414-417.

[54] Sudik SD. Characterization of local chickens in Plateau State, Southern Zone. An Msc Theses. Animal Production Programme, School of Agriculture, ATBU, Bauchi. 2007.

[55] Chambers JP, Fortin A. Live body and carcass measurements as predictors of chemical composition of carcass of male broiler chickens. Poult. Sci. 1984; 63: 2187-2196.

[56] Keambou TC, Manjeli Y, Tchoumboué J, Téguia A. et Iroumé RNDétermination du poids par des mensurations corporelles chez la poule locale des hautes terres de l'ouest Cameroun. Biosciences Proceedings. 2007; 11: 156165. 